Приобретаемые осужденными умения по содержанию делятся:

- на учебные (умение считать, грамотно писать, планировать свою работу, анализировать учебные задачи, искать пути их решения);

— производственно-трудовые организационные, технологические);

(конструктивно-технические,

- общественной деятельности (планировать работу, распределять обязанности, проводить собрания, контролировать выполнение поручений);

— художественной деятельности (игра на музыкальных инструментах, рисование);

- гигиенические (прием пищи, заправка постели, ношение одежды);

- физкультурно-спортивные (в различных видах спорта, связанных с координацией движений и действий);

- личного поведения.

Любое умение включает в себя представления, понятия, знания, навыки концентрации, распределения и переключения внимания, навыки восприятия, мышления, самоконтроля и регулирования процесса деятельности.

Формирование умений включает в себя формирование пластичных, гибких навыков, но для развития умения этого еще недостаточно.

Умение тесно связано с творческим мышлением. Оно опирается не только на навык, но и на знания, поэтому прогрессирует вместе с расширением объема знаний человека, повышением его культурного уровня. [4, С. 312].

Умения не только определяют качество учебной или профессиональной деятельности человека, но и обогащают его опыт, становятся качествами его личности, его умелостью, а он сам - умельцем, мастером своего дела, творцом.

В заключение можем сделать выводы о том, что обучать и готовить осужденных нужно по востребованным профессиям в обществе. Если осужденный будет понимать, что полученная профессия поможет ему построить новую, интересную жизнь после освобождения из колонии, он будет и хорошо учиться и станет на путь исправления и осознания своей вины перед обществом. Поэтому в исправительных учреждениях нужно разрабатывать новые учебные планы и формировать перечень новых специальностей, которые будут востребованы обществом.

$$
* * *
$$

1. Крысько В. Г., Симонович Н. Е. Психологические основы изучения социального самочувствия людей в современном российском обществе //Вестник Университета. 2001.№1. С. 163.

2. Киселева И. А., Симонович Н. Е. Особенности оценки рисков и роль мотивации в период кризиса//Москва, 2016.

3. Симонович Н. Е. Инновационные подходы к обучению личности: (психологическая составляющая) // в сборнике: Психология сознания: Истоки и перспективы изучения. Материалы XIV Международных чтений памяти Л. С. Выготского. 2013. С. 166-167.

4. Симонович Н. Е. Инновационные подходы к образованию//в сборнике: Обучение и развитие: современная теория и практика. Материалы XVI Международных чтений памяти Л. С. Выготского. 2015. С.312.

\title{
Федоров Е.В. \\ Психологические особенности водолазов и пловцов
}

Военно-морской политехнический институт (Россия, Санкт-Петербург)

doi: 10.18411/lj-04-2021-215

\section{Аннотация}

В статье изучаются психологические особенности водолазов и пловцов. У пловцов значимо сильнее выражены стратегии конфронтации и самоконтроля, 
достоверно более низкие показатели самооценки тревожности, фрустрации и агрессивности, достоверно более низкие показатели иррациональных установок: катастрофизации, долженствования в отношении себя, долженствования в отношении других, фрустрационной толерантности и оценочной установки. У водолазов отмечается достоверно более высокий уровень самочувствия и настроения.

Ключевые слова: Водолаз, пловец, психологические особенности.

\section{Abstract}

The article examines the psychological characteristics of divers and swimmers. Swimmers have significantly more pronounced strategies of confrontation and self-control, reliably lower self-assessments of anxiety, frustration and aggressiveness, reliably lower indices of irrational attitudes: catastrophization, obligation towards oneself, obligation towards others, frustration tolerance and evaluative attitude. Divers have a significantly higher level of well-being and mood.

Key words: Diver, swimmer, psychological characteristics.

В настоящее время нет общепринятого определения термина «Риск» [2]. С.И Ожегов определил риск как возможную опасность и действие наудачу в надежде на счастливый исход [1]. Рисковое поведение - это осознанное поведение, несущее в себе принятие элементов риска для здоровья или жизни субъекта, содержащее элемент достижения определенной цели и не очевидный баланс положительных и отрицательных исходов, субъективно воспринимаемый как значимый [9]. Рисковое поведение характерно для экстремальных видов деятельности, например работа водолазом [8].

Это определяет необходимость постоянного совершенствования системы медико-психологического сопровождения водолазов с целью профилактики возникновения у них дезадаптационных расстройств [3, 7]. Дезадаптационные расстройства определяются в том числе личностными особенностями [12], психическими состояниями [4], ценностно-мотивационной структурой [11] и механизмами преодоления эмоционального стресса [10], которые определяют развитие и формирование различных вариантов поведения, приводящих к адаптации, либо дезадаптации индивида. Эти поведенческие модели могут сменять друг друга, претерпевая определенное прогрессивное развитие, и могут носить ригидный, фиксированный характер с последовательным усложнением, приводящим к возникновению нарушений [5].

Цель работы. Выявить взаимосвязь психологических показателей водолазов со склонностью к риску.

Материалы и методы. Обследовано 52 военнослужащих Военно-морского политехнического института. Из них 30 водолазы и 22 спортсмены - пловцы в возрасте от 23 до 28 лет. Обследование проводилось с помощью методики диагностики степени готовности к риску Шуберта, теста самооценки самочувствия, активности, настроения $(\mathrm{CAH})$, теста копинг-поведения Р. Лазаруса, методики для оценки наличия и выраженности иррациональных установок А.Эллиса, методики самооценки психических состояний (Г.Айзенк). Статистическая обработка проводилась с использованием пакета программ Statistica 10,0. Сравнительный анализ проводился с использованием критерия $\mathrm{t}$-Стьюдента. Взаимосвязи определялись с помощью коэффициента ранговой корреляции Спирмена [6].

Результаты и их обсуждение. Анализ склонности к риску по методике Шуберта у военнослужащих различного профиля (водолазов и пловцов) позволил выявить следующие особенности. Выяснилось, что у военнослужащих экстремального профиля - водолазов низкий уровень склонности к риску отмечался в $18 \%$ случаев, 
средний - в 35\%, высокий - в 47\%; в то же время у пловцов низкий уровень склонности к риску был в $34 \%$ случаев, средний - в $46 \%$ и высокий - в $20 \%$ случаев.

Водолазы, по сравнению с пловцами, более склонны к риску, что, по-видимому, связано со спецификой их специализации, которая требует большей способности проявлять рискованное поведение (табл. 1.).

Таблий 1

Склонность к риску у водолазов и пловцев, $x \pm \sigma$

\begin{tabular}{|c|c|c|}
\hline Показатель & Пловцы & Водолазы \\
\hline Склонность к риску & $2,4 \pm 3,8$ & $9,1 \pm 4,2^{*}$ \\
\hline
\end{tabular}

Примечание: *-различия в группах статистически значимы при $p<0,05$

У пловцов значимо сильнее выражены стратегии конфронтации и самоконтроля. На уровне тенденций обнаруживаются также различия в выраженности стратегии избегания (табл. 2):

Таблица 2

Результаты теста Лазаруса у водолазов и пловцов, $x \pm \sigma$

\begin{tabular}{|c|c|c|}
\hline Копинг-стратегии & Пловцы & Водолазы \\
\hline Самоконтроль & $16,1 \pm 2,9$ & $14 \pm 3,0^{*}$ \\
\hline Поиск поддержки & $11,9 \pm 3,2$ & $11,9 \pm 3,1$ \\
\hline Принятие ответственности & $8,7 \pm 2,5$ & $7,8 \pm 2,1$ \\
\hline Планирование решения проблемы & $15,7 \pm 3,6$ & $16,0 \pm 3,1$ \\
\hline Положительная переоценка & $11,8 \pm 3,9$ & $10,5 \pm 3,2$ \\
\hline Дистанцирование & $13,2 \pm 3,2$ & $11,7 \pm 3,2$ \\
\hline Избегание & $11,53 \pm 3,4$ & $9,3 \pm 4,0$ \\
\hline Конфронтация & $13,1 \pm 3,1$ & $10,1 \pm 2,7^{*}$ \\
\hline
\end{tabular}

Примечание: *-различия в группах статистически значимы при $p<0,05$

У военнослужащих различного профиля (водолазов и пловцов) определялись некоторые особенности в их самочувствии, активности и настроении (табл. 3).

Таблиия 3

Самочувствие, активность и настроение у водолазов и пловиов, $x \pm \sigma$

\begin{tabular}{|c|c|c|}
\hline Показатель & Пловцы & Водолазы \\
\hline Самочувствие & $3,8 \pm 0,2$ & $5,1 \pm 0,3^{*}$ \\
\hline Активность & $3,9 \pm 0,3$ & $4,2 \pm 0,1$ \\
\hline Настроение & $4,3 \pm 0,2$ & $5,6 \pm 0,2^{*}$ \\
\hline
\end{tabular}

Примечание: * - различия в группах статистически значимы при $p<0,05$

У водолазов, по сравнению с пловцами, отмечались достоверно более высокие показатели по шкалам самочувствия и настроения по методике $\mathrm{CAH}(\mathrm{p}<0,05)$. При этом по всем шкалам (самочувствие, активность и настроение) у пловцов показатели находятся ниже 5 баллов, что свидетельствует о развитии у них неблагоприятного психического состояния, отражающего психологическон неблагополучие.

Уточнение самооценки психических состояний, позволяющих оценить степень выраженности тревожности, фрустрации, агрессивности и ригидности по методике Г. Айзенка у водолазов и пловцов позволило выявить следующие особенности (табл. 4)

Таблиия 4

Самооценка психического состояния у водолазов и пловиов, $x \pm \sigma$

\begin{tabular}{|c|c|c|}
\hline Показатель & Пловцы & Водолазы \\
\hline Тревожность & $18,9 \pm 2,1$ & $8,2 \pm 1,2$ \\
\hline Фрустрация & $15,4 \pm 1,2$ & $7,1 \pm 0,9$ \\
\hline Агрессивность & $12,5 \pm 1,3$ & $6,4 \pm 1,1$ \\
\hline Ригидность & $7,6 \pm 1,1$ & $8,5 \pm 1,2$ \\
\hline
\end{tabular}

Примечание: *-различия в группах статистически значимы при $p<0,05$ 
Выяснилось, что пловцы имеют достоверно более низкие показатели тревожности, фрустрации и агрессивности $(\mathrm{p}<0,05)$.

Таким образом, у водолазов показатели тревожности, фрустрации, агрессивности и ригидности не выходили за пределы средних значений и для них было в целом характерно оптимальное психическое состояние, не снижающее их работоспособность и общее самочувствие.

В то же время у спортсменов-пловцов показатели тревожности, фрустрации и агрессивности были выше среднего, проявляющиеся в повышенной тревожности, беспричинном беспокойстве, избегании ответственности, занижении самооценки, повышении агрессивности и трудности общения с другими людьми, что свидетельствует об ухудшении их самочувствия и качества жизни в целом.

Отношение к экстремальным ситуациям зависит от того, каковы установки у человека по отношению к неблагоприятным событиям, требований к себе и окружающим людям, фрустрационной устойчивости и готовности рационально преодолевать возникающие препятствия.

Иррациональные установки оценивались по методике Эллиса у военнослужащих различного профиля (водолазов и пловцов).

Оказалось, что пловцы, по сравнению с водолазами обладают достоверно более низкими показателями по всем шкалам методики для определения иррациональных установок - катастрофизации ( $<0,05)$, «долженствования в отношении себя» $(\mathrm{p}<0,05)$, «долженствования в отношении других» $(\mathrm{p}<0,05)$, фрустрационной толерантности $(\mathrm{p}<0,05)$ и «оценочной установки» $(\mathrm{p}<0,05)$ (табл. 5$)$.

Таблицุа 5

Иррациональные установки у водолазов и пловиов, $x \pm \sigma$

\begin{tabular}{|c|c|c|}
\hline Показатель & Пловцы & Водолазы \\
\hline Катастрофизация & $28,9 \pm 2$ & $35,2 \pm 1,8^{*}$ \\
\hline Долженствование в отношении себя & $29,9 \pm 2,3$ & $32,3 \pm 1,4^{*}$ \\
\hline Долженствование в отношении других & $30,4 \pm 0,9$ & $35,5 \pm 1,6^{*}$ \\
\hline Фрустрационная толерантность & $29,2 \pm 1,5$ & $32,7 \pm 1,9^{*}$ \\
\hline Оценочная установка & $28,4 \pm 2,3$ & $33,5 \pm 2,8^{*}$ \\
\hline
\end{tabular}

Примечание: *-различия в группах статистически значимы при $p<0,05$

То есть у пловцов имеется большая склонность оценивать каждое неблагоприятное событие как ужасное и невыносимое, чрезмерно высокие требования к себе и другим, направленность на обобщенную оценку личности по отдельным деталям, а также снижение компенсаторно-приспособительных способностей.

И наоборот, для водолазов характерны относительно адекватные требования к себе и другим, отсутствие склонности выносить общее суждение о личности по отдельным деталям поведения, высокая фрустрационная толерантность и рациональность мышления.

\section{Выводы}

1. У пловцов значимо сильнее выражены стратегии конфронтации и самоконтроля, достоверно более низкие показатели самооценки тревожности, фрустрации и агрессивности, достоверно более низкие показатели иррациональных установок: катастрофизации, долженствования в отношении себя, долженствования в отношении других, фрустрационной толерантности и оценочной установки.

2. $\quad$ У водолазов отмечается достоверно более высокий уровень самочувствия и настроения.

\section{$* * *$}

1. Быков А.А., Порфирьев Б.Н. Об анализе риска, концепциях и классификации рисков // Проблемы анализа риска. 2006. Т. 3. № 4. С. 319-337. 
2. Голубева С.С., Голубниченко М.В. Современные подходы к изучению риска // Математическое и компьютерное моделирование в экономике, страховании и управлении рисками. 2020. № 5. С. 162 165.

3. Днов К.В., Серегин Д.А., Ятманов А.Н. Профилактика суицидального поведения и медикопсихологическое сопровождение военнослужащих. Казань, 2017. 96 с.

4. Днов К.В., Зайцев А.Г., Серегин Д.А., Ятманов А.Н. Влияние психических состояний на военнопрофессональную адаптацию курсантов военного вуза // Medline.ru. Российский биомедицинский журнал. 2018. Т. 19. № 1. С. 344-351.

5. Зайцев А.Г., Резванцев М.В., Тегза В.Ю., Ятманов А.Н., Дергачев В.Б. Математическая модель прогноза успешности военно-профессиональной адаптации курсантов военно-морской академии им. Н.Г. Кузнецова // Вестник Российской Военно-медицинской академии. 2018. № 1 (61). С. 160163.

6. Наследов А.Д. Математические методы психологического исследования. Учебное пособие для студентов высших учебных заведений, обучающихся по направлению и по специальностям психологии. Санкт-Петербург, 2012. 325 с.

7. Солодков А.С., Юсупов В.В., Днов К.В., Туманова Н.Н., Ятманов А.Н. Медико-психологическое сопровождение кандидатов на поступление в военный ВУЗ // Ученые записки университета им. П.Ф. Лесгафта. 2015. № 5 (123). С. 258-263.

8. Федоров Е.В., Ятманова Т.М., Ятманов А.Н. Оценка психофизиологических показателей у водолазов - профессионалов и аквалангистов-любителей устойчивых и неустойчивых к декомпрессионному воздействию // Здоровье - основа человеческого потенциала: проблемы и пути их решения. 2015. Т. 10. № 1. С. 439-441.

9. Хотинец В.Ю. Копинг-поведение в ситуации вызовов и рисков // Контакты и взаимодействие культур. ХІ Конгресс антропологов и этнологов России. 2015. С. 112.

10. Ятманова Т.М., Ятманов А.Н., Лобачев А.В. Оценка стрессоустойчивости военнослужащихженщин // Здоровье - основа человеческого потенциала: проблемы и пути их решения. 2011. Т. 6. № 1. С. 521-522.

11. Ятманов А.Н., Блеер А.Н. Ценностно-мотивационная структура курсантов Военно-морской академии // Спортивный психолог. 2017. № 3 (46). С. 24-26.

12. Ятманов А.Н. Личностные особенности моряков // Здоровье - основа человеческого потенциала: проблемы и пути их решения. 2016. Т. 11. № 2. С. 676-677. 